\title{
Variasi Morfologi dan Kelimpahan Kepiting Uca spp. di Kawasan Mangrove, Tuban-Bali
}

\author{
Yuli Krisnawati a*, I Wayan Arthana ${ }^{a}$, Ayu Putu Wiweka Krisna Dewi ${ }^{a}$ \\ a Program Studi Manajemen Sumberdaya Perairan, Fakultas Kelautan dan Perikanan, Universitas Udayana, Bukit Jimbaran, \\ Bali 80361, Indonesia \\ * Penulis koresponden. Tel.: +62-85655936609 \\ Alamat e-mail: yulikrisnawati17@gmail.com
}

Diterima (received) 19 Juni 2017; disetujui (accepted) 1 November 2017; tersedia secara online (available online) 3 November 2017

\begin{abstract}
Fiddler crabs (Uca spp.) are one of the mangrove fauna that has an important role of food chain within the scope of mangrove, which is as a deposit eater. The mangrove area in Kampoeng Kepiting has been damaged due to reclamation for Bali Mandara toll road construction, which can interfere the survival/existence of Fiddler crabs. Therefore, it is necessary to do a research concerning the abundance of Fiddler Crabs in Kampoeng Kepiting mangrove area. The aim of this study is to determine the type and abundance of Fiddler crabs and to discover the coherency among Fiddler Crabs abundance in the manner of c-organic matter content in Kampoeng Kepiting area. Fiddler crabs samples were carried out using $1 \times 1$ meter quadrant transect by digging as deep as $30 \mathrm{~cm}$. The abundance of Fiddler crabs was analyzed under the Krebs equation. The results from this study indicate Fiddler crabs were found in Kampoeng Kepiting area ,i.e. Uca demani, Uca coarctata, Uca dussumieri, Uca bellator, Uca lactea perplexa, Uca tetragonon, Uca chlorophthalmus crassipes, Uca lactea annulipes, Uca triangularis, and Uca vocans. The highest Fiddler crabs abundance were found at station 4 which is $72 \pm 4,2$ ind $/ \mathrm{m}^{2}$, whilst the abundance of Fiddler crabs (Uca spp.) at station 5 is $\left(33 \pm 1,2 \mathrm{ind} / \mathrm{m}^{2}\right)$. The c-organic matter content has a strong relationship with the abundance of Fiddler crabs in Kampoeng Kepiting mangrove area $(r=0,91)$. This study shows that mangrove conditions in Kampoeng Kepiting are still able to support Fiddler Crabs (Uca spp.) existence
\end{abstract}

Keywords : abundance; c-organic; fiddler crabs; uca.

\begin{abstract}
Abstrak
Kepiting Uca merupakan fauna mangrove yang memiliki peranan penting bagi mangrove yaitu sebagai pemakan deposit. Kawasan mangrove di Kampoeng Kepiting telah mengalami kerusakan akibat reklamasi untuk pembuatan jalan tol, sehingga dapat mengganggu kelangsungan hidup Kepiting Uca. Oleh karena itu, perlu dilakukan penelitian mengenai kelimpahan Kepiting Uca di kawasan mangrove Kampoeng Kepiting. Tujuan penelitian ini adalah untuk mengetahui jenis dan kelimpahan kepiting Uca serta mengetahui hubungan antara kandungan c-organik dengan kelimpahan Kepiting Uca di kawasan mangrove Kampoeng Kepiting. Pengambilan sampel Kepiting Uca dilakukan dengan menggunakan transek ruang yang berukuran 1 x 1 meter dengan cara digging sedalam $30 \mathrm{~cm}$. Kelimpahan Kepiting Uca dianalisa dengan persamaan Krebs. Hasil penelitian menunjukkan bahwa Kepiting Uca yang terdapat pada kawasan mangrove Kampoeng Kepiting yaitu Uca demani, Uca coarctata, Uca dussumieri, Uca bellator, Uca lactea perplexa, Uca tetragonon, Uca chlorophthalmus crassipes, Uca lactea annulipes, Uca triangularis, dan Uca vocans. Kelimpahan kepiting Uca tertinggi terdapat pada stasiun 4 yaitu sebesar $72 \pm 4,2 \mathrm{ind} / \mathrm{m}^{2}$, sedangkan kelimpahan terendah pada stasiun $5\left(33 \pm 1,2\right.$ ind $\left./ \mathrm{m}^{2}\right)$. Kandungan c-organik memiliki hubungan yang kuat dengan kelimpahan kepiting Uca di kawasan mangrove Kampoeng Kepiting $(r=0,91)$. Hal ini menunjukkan bahwa kondisi mangrove di Kampoeng Kepiting masih mampu menunjang kehidupan Kepiting Uca.
\end{abstract}

Kata kunci : c-organik, kepiting uca, kelimpahan 


\section{Pendahuluan}

Kepiting adalah jenis krustasea yang telah banyak dikenal dan dimanfaatkan oleh masyarakat. Selain fungsi ekonomi, kepiting juga memiliki fungsi ekologi salah satunya yaitu sebagai pemakan deposit. Jenis dan sebaran kepiting pemakan deposit sangat ditentukan oleh tipe sedimen. Salah satu jenis kepiting deposit yaitu Kepiting Uca (Crane, 2015). Kepiting Uca merupakan jenis kepiting yang menyaring mikroorganisme dari permukaan sedimen dan mencernanya sebagai makanan (Murniati, 2010).

Jumlah jenis Kepiting Uca yang ada di dunia mencapai 97 jenis. Jumlah tersebut, hanya sekitar 19 jenis yang ada di Indonesia. Hal ini dikarenakan tidak semua jenis Kepiting Uca mampu hidup dan bertahan di berbagai wilayah belahan dunia. Karakteristik yang dimiliki oleh masing-masing Kepiting Uca juga dapat menunjukkan wilayah penyebarannya, termasuk jenis Kepiting Uca yang berada di kawasan Indonesia (Arsana, 2010).

Kepiting Uca sebagai salah satu fauna mangrove, kurang mendapatkan perhatian dalam upaya perlindungan karena kurang dimanfaatkan oleh manusia (Holtermann et al., 2009; Natania, 2017). Meskipun kondisi Kepiting Uca sekarang masih banyak, namun dengan meningkatnya aktivitas dan kegiatan manusia pada ekosistem mangrove akan berdampak langsung terhadap kelimpahan dan keanekaragaman jenisnya (Cannicci et al., 2009). Diperlukan data jenis dan kelimpahan Kepiting Uca, sehingga dilakukan penelitian "Variasi Morfologi dan Kelimpahan Kepiting Uca spp. di Kawasan Mangrove, TubanBali". Penelitian ini bertujuan untuk mengetahui jenis dan kelimpahan Kepiting Uca serta untuk mengetahui hubungannya dengan kandungan corganik .

\section{Metode Penelitian}

\subsection{Waktu dan Lokasi Penelitian}

Penelitian ini merupakan penelitian deskriptif kuantitatif dengan pendekatan metode observasi langsung yang dilakukan di ekosistem mangrove Kampoeng Kepiting, Tuban-Bali (Gambar 1). Waktu pengambilan data dilakukan pada Bulan Januari - Februari 2017.

Analisis sampel Kepiting Uca dilakukan di Laboratoriun Manajemen Sumberdaya Perairan
Fakultas Kelautan dan perikanan. Sedangkan uji kandungan c-organik dilakukan di Laboratorium Tanah Fakultas Pertanian Universitas Udayana.

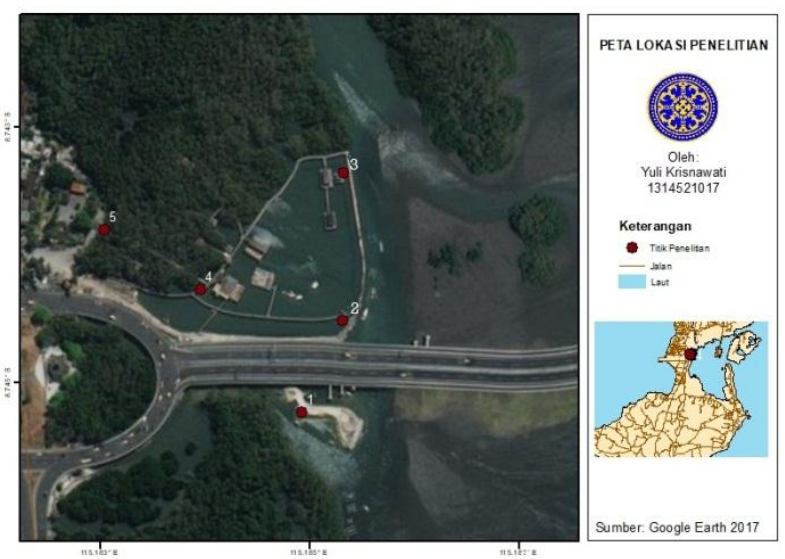

Gambar 1. Peta lokasi penelitian

\subsection{Alat dan Bahan}

Alat yang digunakan dalam penelitian disajikan dalam Tabel 1.

Tabel 1

Alat yang digunakan dalam penelitian

\begin{tabular}{ll}
\hline \multicolumn{1}{c}{ Alat } & \multicolumn{1}{c}{ Kegunaan } \\
\hline $\begin{array}{l}\text { Transek } 1 \times 1 \mathrm{~m} \\
\text { dengan tinggi } \\
50 \mathrm{~cm}\end{array}$ & $\begin{array}{l}\text { Untuk menenukan stasiun titik } \\
\text { penelitian }\end{array}$ \\
$\begin{array}{l}\text { Geographic } \\
\text { Positioning } \\
\text { System (GPS) } \\
\text { Cetok kecil }\end{array}$ & $\begin{array}{l}\text { Untuk menentukan dan mengetahui } \\
\text { titik koordinat lokasi penelitian }\end{array}$ \\
& Untuk melakukan digging atau \\
Kantong & penggalian lubang Kepiting Uca \\
plastik (zipper & Untuk meyimpan substrat \\
bag) & \\
Kamera & Untuk dokumentasikan \\
Toples & Untuk menyimpan sampel uca \\
Sarung tangan & Untuk melindungi tangan pada saat \\
gloves) & pengambilan sampel Kepiting Uca \\
Sepatu boat & Untuk melindungi kaki pada area \\
& kawasan mangrove dengan keadaan \\
bool Box & Untumpur \\
Refraktometer & Untuk mengukur salinitas \\
pH meter & Untuk mengukur kadar keasaaman \\
& dan suhu \\
Timbangan & Untuk menimbang berat sampel \\
analitik & sedimen \\
\hline &
\end{tabular}

Bahan yang digunakan dalam penelitian disajikan pada Tabel 2. 
Tabel 2

Bahan yang digunakan dalam penelitian

\begin{tabular}{ll}
\hline \multicolumn{1}{c}{ Bahan } & \multicolumn{1}{c}{ Kegunaan } \\
\hline Formalin $4 \%$ & Untuk mengawetkan sampel Uca \\
Alkohol 70\% & Untukmenyimpan sampel uca \\
Aquades & Untuk mensterilkan alat \\
Sampel & $\begin{array}{l}\text { Untuk mengetahui kandungan } \\
\text { bubstrat }\end{array}$ \\
\hline
\end{tabular}

\subsection{Metode Pengambilan Data}

\subsubsection{Penentuan titik stasiun}

Metode yang digunakan dalam penentuan lokasi penelitian ini adalah metode purposive sampling. Terdapat 5 titik stasiun dengan kondisi substrat yang berbeda dalam penelitian ini (Tabel 3).

\section{Tabel 3}

Karakteristik Lokasi Penelitian

\begin{tabular}{cl}
\hline Stasiun & \multicolumn{1}{c}{ Karakteristik Lokasi penelitian } \\
\hline 1 & $\begin{array}{l}\text { Tanah berbatu (daerah dekat pasang } \\
\text { surut) pertemuan air laut dan air sungai }\end{array}$ \\
2 & $\begin{array}{l}\text { Tanah berkapur, dekat jalan tol } \\
\text { Mandara Bali }\end{array}$ \\
3 & Lumpur berbatu (dekat muara sungai) \\
4 & Lumpur halus \\
5 & Tanah berliat (jauh dari masukan air) \\
\hline
\end{tabular}

\subsubsection{Pengambilan sampel Kepiting Uca}

Pengambilan sampel Kepiting Uca dilakukan dengan cara metode digging. Metode digging yaitu penggalian lubang Kepiting Uca sedalam $30 \mathrm{~cm}$ untuk mendapatkan sampel Kepiting Uca. Penggalian dilakukan dengan menggunakan alat cetok kecil. Penggalian dilakukan di dalam transek berukuran 1 x 1 meter.

\subsubsection{Pengambilan sampel substrat}

Pengambilan sampel substrat menggunakan alat cetok kecil lalu sampel substrat dimasukkan ke dalam kantong plastik kurang lebih sebanyak 50 gram. Pengambilan substrat dilakukan untuk diuji kandungan c-organik yang terkandung dalam sampel substrat tersebut.

\subsubsection{Pengambilan Data Prameter Kualitas Air}

Data kualitas air yang diukur yaitu parameter kimia dan fisika. Parameter kimia meliputi salinitas yang diukur menggunakan refraktometer, dan $\mathrm{pH}$ yang diukur menggunakan $\mathrm{pH}$ meter. Sedangkan parameter fisika yang diambil yaitu suhu yang diukur menggunakan thermometer. Pengambilan data kualitaas air ini dilakukan secara insitu pada masing-masing setiap titik penelitian.

\subsection{Analisis Data}

\subsubsection{Identifikasi Kepiting Uca}

Identifikasi dilakukan untuk mengetahui jenis individu Kepiting Uca. Pedoman yang digunakan dalam identifikasi ini yaitu menggunakan buku kunci identifikasi menurut Crane (2015).

\subsubsection{Kandungan Bahan Organik}

Kandungan bahan organik diuji di laboratorium Ilmu Tanah Fakultas Pertanian Universitas Udayana dengan menggunakan metode Walkley dan Black. Pengukuran kandungan bahan organik dengan menggunakan metode Walkey dan Black ditentukan berdasarkan kandungan C-organik (Foth, 1984).

\subsubsection{Kelimpahan Kepiting Uca}

Kelimpahan individu Kepiting Uca didefinisikan sebagai jumlah individu spesies setiap titik. Persamaan kelimpahan Kepiting Uca yang digunakan dalam penelitian ini adalah:

$$
D i=\frac{n i}{A}
$$

2.4.4 Hubungan Kelimpahan Kepiting Uca dengan Bahan Organik

Hubungan antara kelimpahan jumlah Kepiting Uca dengan bahan organik digunakan dua analisa perhitungan yaitu korelasi dan regresi dengan menggunakan bantuan program komputer Microsoft Exel.

\section{Hasil dan Pembahasan}

\subsection{Jenis dan Kelimpahan Kepiting Uca}

Jenis Kepiting Uca yang didapatkan dari hasil penelitian ini diidentifikasi berdasarkan ciri-ciri 
morfologi. Kelimpahan Kepiting Uca didapat dengan cara menghitung jumlah Kepiting Uca yang ditemukan di stasiun penelitian per luas area penangkapan. Hasil identifikasi Jenis Kepiting Uca dapat dilihat pada Gambar 2.

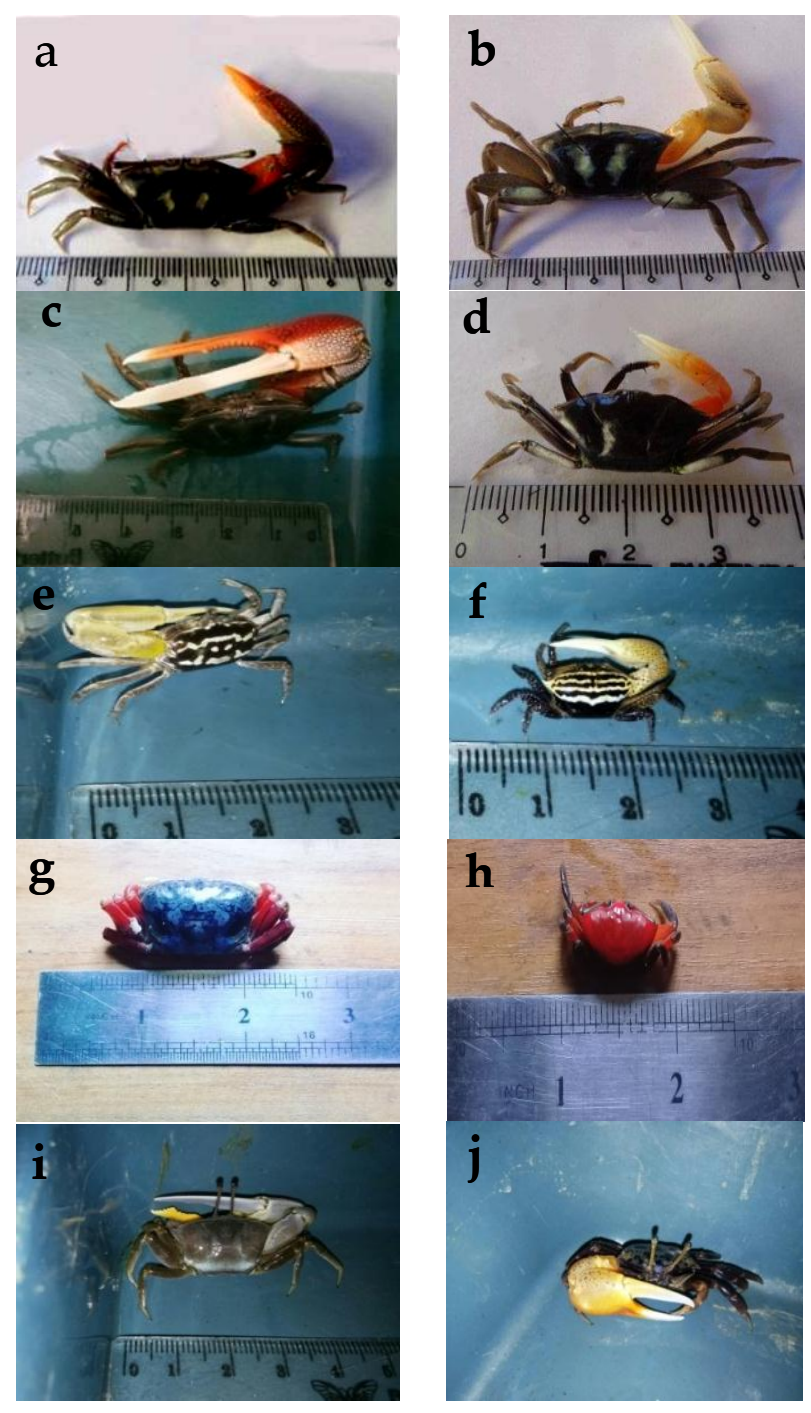

Gambar 2. Jenis Kepiting Uca yang ditemukan a.Uca demani; b.Uca coarctata; c.Uca dussumieri; d.Uca bellator; e.Uca lactea perplexa; f.Uca tetragonon; g.Uca chlorophthalmus crassipes; h.Uca lactea annulipes; i.Uca triangularis; j.Uca vocans.

Jumlah Kepiting Uca yang didapatkan dari kelima stasiun berjumlah 10 jenis. Jumlah Kepiting Uca yang didapat dari penelitian ini lebih tinggi dari hasil penelitian Hamidy (2012) di ekosistem Mangrove Desa Purnama Dumai Riau. Hamidy (2012) hanya menemukan 5 jenis yaitu Uca vocans, Uca annulipes, Uca rosea, Uca dussumieri, dan Uca pugilator. Tingginya kandungan c-organik jumlah jenis Kepiting Uca yang ditemukan menunjukkan bahwa habitat di kawasan mangrove Kampoeng
Kepiting masih dalam keadaan bagus dan masih sesuai untuk kehidupan Kepiting Uca. Sunaryo (2014) menjelaskan bahwa jumlah jenis biota cenderung rendah apabila secara fisika kondisi suatu ekosistem kurang baik.

Kelimpahan Kepiting Uca yang ditemukan pada masing-masing stasiun cenderung berbeda. Kelimpahan total Kepiting Uca dapat dilihat pada Tabel 4.

Tabel 4

Kelimpahan Kepiting Uca

\begin{tabular}{|c|c|c|c|c|c|c|}
\hline \multirow{2}{*}{ No } & \multirow{2}{*}{$\begin{array}{c}\text { Jenis Kepiting } \\
\text { Uca }\end{array}$} & \multicolumn{5}{|c|}{ Stasiun } \\
\hline & & 1 & 2 & 3 & 4 & 5 \\
\hline 1. & Uca demani & 14 & 1 & 14 & 8 & 5 \\
\hline 2. & Uca coarctata & 5 & 1 & 3 & 19 & 5 \\
\hline 3. & Uca dussumieri & 11 & 5 & 14 & 25 & 6 \\
\hline 4. & Uca bellator & 5 & 20 & 7 & 8 & 4 \\
\hline 5. & $\begin{array}{l}\text { Uca lactea } \\
\text { perplexa }\end{array}$ & - & 13 & 4 & 3 & 4 \\
\hline 6. & Uca tetragonon & - & 2 & 0 & - & 3 \\
\hline \multirow[t]{2}{*}{7.} & Uca & & & & & \\
\hline & $\begin{array}{l}\text { chlorophthalmus } \\
\text { crassipes }\end{array}$ & - & 1 & - & - & - \\
\hline 8. & $\begin{array}{l}\text { Uca lactea } \\
\text { annulipes }\end{array}$ & - & 1 & 7 & 2 & 3 \\
\hline 9. & Uca triangularis & - & 4 & 1 & 3 & 1 \\
\hline 10. & Uca vocans & 1 & - & 3 & 4 & 2 \\
\hline \multicolumn{2}{|c|}{ Kelimpahan (ind $/ \mathrm{m}^{2}$ ) } & 36 & 48 & 53 & 72 & 33 \\
\hline
\end{tabular}

Kepiting Uca yang didapat dari kelima stasiun menyukai habitat yang berbeda-beda. Jenis $U_{c a}$ Demani, Uca Coarctata, Uca dussumieri dan Uca bellator merupakan Kepiting Uca yang ditemukan pada kelima stasiun dengan kelimpahan total yang tinggi (Tabel 4). Keempat jenis Kepiting Uca tersebut diduga memiliki adaptasi toleransi yang lebih tinggi terhadap perbedaan substrat dibandingkan jenis Kepiting Uca yang lain. Hal ini didukung juga oleh pendapat Murniati (2009) dan Loviasari dkk. (2018), berdasarkan hasil penelitiannya bahwa Uca Demani dan Uca dussumieri merupakan jenis Kepiting Uca yang mampu bertahan pada habitat (substrat) yang berbeda.

Secara keseluruhan jenis kepiting Uca demani cukup banyak ditemukan dan sering muncul pada setiap stasiun. Tingginya jumlah Uca demani ini berkaitan dengan pola hidupnya. Uca demani sangat aktif bergerak dan mencari makan di permukaan substrat (Watiniasih, 2015). Dengan demikian, Uca demani memiliki peluang makan 
dan adaptasi yang lebih tinggi dibandingkan dengan jenis Kepiting Uca lain yang memiliki kisaran tempat makan dan ruang gerak lebih sempit. (Crane, 2015) menyatakan bahwa Uca demani memiliki toleransi yang cukup terhadap lingkungan biasa sampai ekstrim, dan menyukai substrat berlumpur dan berpasir. Uca demani juga memiliki ciri-ciri morfologi bentuk tubuh yang besar, diduga Uca demani lebih sering menyerang Kepiting Uca yang lain (kanibalisme). Sifat kepiting yang mencolok yaitu sifat kanibalisme dan saling menyerang (Milner et al., 2010).

Jenis Uca dussumieri juga sering muncul dan mendominasi di beberapa stasiun. Uca dussumieri memiliki jumlah paling banyak di stasiun 3 dan 4 . Berdasarkan hasil uji kandungan c-organik, stasiun 4 didapatkan nilai c-organik tertinggi. Hal ini diduga karena habitat cocok (substrat). Menurut Weis and Weis (2004), Uca dussumieri hidup di habitat dengan kandungan bahan organik yang tinggi. Pratiwi (2012), juga menyatakan bahwa Uca dussumieri mampu beradaptasi secara baik terhadap faktor-faktor lingkungan yang sangat luas yang ada di ekosistem. Sehingga kepiting jenis ini ditemukan melimpah di beberapa stasiun yang memiliki salinitas yang berbeda.

Selain Uca demani dan Uca dussumieri, Jenis Uca bellator juga ditemukan di kelima stasiun pengamatan. Uca bellator ditemukan mendominasi keberadaanya di stasiun 2 dengan kondisi substrat tanah berkapur dan sangat dekat dengan sungai. Lokasi stasiun 2 ini merupakan bekas reklamasi jalan tol sehingga terdapat kerikil-kerikil batu kapur. Namun, Kepiting Uca jenis Uca bellator justru mendominasi pada stasiun 2. Hal ini diduga bahwa Uca bellator menyukai habitat tanah berkapur. Uca bellator juga sangat toleran terhadap salinits rendah. Crane (2015) menyatakan bahwa Uca bellator menyukai habitat daerah masukan air sungai.

Jenis Uca coarctata juga merurpakan jenis Kepiting Uca yang ditemukan keberadaanya pada kelima stasiun meskipun dengan jumlah individu yang tidak terlalu besar di beberapa stasiun. Uca coarctata ditemukan mendominasi pada stasiun 4 dengan kondisi substat berlumpur. Hal ini sesuai dengan pernyataan Pratiwi (2012) bahwa Uca coarctata hidup pada subtrat lumpur halus biasanya pada permukaan lubang berbentuk seperti corong. Penelitian mengenai kelimpahan jenis kepiting Uca juga pernah dilakukan di Jambi,
Jabung Timur yang menyatakan bahwa $U_{c a}$ coarctata merupakan Uca yang jumlahnya paling sedikit dibandingkan dengan jenis Kepiting Uca yang lain, karena Uca coarctata kurang bisa beradaptasi dengan habitat kering dengan salinitas rendah (Penha-Lopes et al., 2009).

Jenis Kepiting Uca yang sangat jarang ditemukan yaitu Uca chlorophthalmus crassipes. Kepiting Uca jenis chlorophthalmus crassipes ini mempunyai ciri-ciri warna merah yang mencolok. Uca chlorophthalmus crassipes menyukai habitat berpasir dan jauh dari batas air. Habitat pada stasiun 2 (pasir berkerikil) seharusnya cocok untuk menunjang kehidupan Uca jenis chlorophthalmus crassipes. Dari hasil yang didapat selama penelitian, Uca chlorophthalmus crassipes memang ditemukan pada stasiun 2, namun dengan jumlah yang sangat sedikit yaitu 1 ekor (Tabel 4). Uca chlorophthalmus crassipes memiliki warna yang indah dan mencolok. Hal ini diduga dapat menjadi daya tarik bagi kepiting jenis lain yang menyebabkan terjadinya persaingan antar jenis kepiting, sehingga keberadaan Uca chlorophthalmus crassipes terancam yang mengakibatkan kelimpahan jenis $U c a$ chlorophthalmus crassipes sangat sedikit. Crane (2015) menyatakan bahwa semakin menarik warna, semakin rentan terjadi perkelahian antar jenis spesies.

Terdapat kelimpahan total tertinggi pada stasiun 4, hal ini diduga karena stasiun 4 memiliki kandungan c-organik tertinggi dibandingkan stasiun yang lain. Selain itu, kondisi substrat pada stasiun 4 yaitu lumpur halus yang sangat memungkinkan untuk kehidupan Kepiting Uca yang menyukai habitat lumpur. Lokasi stasiun 4 berada sangat dekat dengan mangrove yang padat, sehingga mendapatkan kandungan organik dari serasah mangrove yang cukup besar. Bernini (2010), menyatakan bahwa kelimpahan jenis dan kelimpahan total kepiting dipengaruhi oleh kondisi kerapatan tumbuhan mangrove yang masih baik.

\subsection{Parameter Kualitas Air}

Hasil pengukuran parameter kualitas air pada kelima stasiun yang dilakukan di Kampoeng Kepiting, Tuban-Bali ditunjukkan pada Tabel 5 . Nilai suhu perairan pada setiap stasiun memiliki nilai yang tidak jauh berbeda. Kisaran yang didapat dari hasil pengukuran antara $27-31^{\circ} \mathrm{C}$. Kisaran suhu ini masih sangat bagus untuk 
Tabel 5

Parameter Kualitas Perairan

\begin{tabular}{ccccc}
\hline Stasiun & Suhu $\left({ }^{\circ} \mathbf{C}\right)$ & Salinitas (ppt) & pH & C-organik (\%) \\
\hline 1 & $29,93 \pm 1,99$ & $19,5 \pm 1,16$ & $7,47 \pm 0,12$ & 1,21 \\
2 & $28,34 \pm 1,21$ & $25,5 \pm 2,08$ & $7,44 \pm 0,18$ & 1,22 \\
3 & $29,02 \pm 1,99$ & $24,6 \pm 1,84$ & $7,49 \pm 0,2$ & 1,22 \\
4 & $27,69 \pm 0,93$ & $30,8 \pm 2,38$ & $7,41 \pm 0,14$ & 3,45 \\
5 & $31,04 \pm 2,14$ & $19,7 \pm 1,7$ & $7,25 \pm 0,2$ & 0,63 \\
\hline
\end{tabular}

kehidupan Kepiting Uca. Menurut Budiman et al. (2014), suhu yang sesuai untuk kehidupan Kepiting Uca adalah $18-35^{\circ} \mathrm{C}$, sedangkan suhu ideal adalah $25-30^{\circ} \mathrm{C}$. Hal ini menunjukkan bahwa suhu rata-rata di kawasan mangrove Kampoeng Kepiting dapat menunjang pertumbuhan dan perkembangan Kepiting Uca.

Nilai suhu perairan pada setiap stasiun memiliki nilai yang tidak jauh berbeda (Tabel 5). Kisaran yang didapat dari hasil pengukuran antara $27-31^{\circ} \mathrm{C}$. Kisaran suhu ini masih sangat bagus untuk kehidupan Kepiting Uca. Menurut Pratiwi (2010), suhu yang sesuai untuk pertumbuhan dan kehidupan Kepiting Uca yaitu antara $18-35^{\circ} \mathrm{C}$, sedangkan suhu idealnya adalah 25-30․ Hal ini menunjukkan bahwa suhu ratarata di kawasan mangrove Kampoeng Kepiting masih dapat menunjang pertumbuhan dan perkembangan Kepiting Uca.

Berdasarkan Tabel 5, nilai pada setiap stasiun tidak memiliki perbedaan yang besar. $\mathrm{pH}$ dalam penelitian ini adalah berkisar antara 7,25-7,49. Kisaran nilai $\mathrm{pH}$ yang diperoleh selama penelitian termasuk dalam kategori baik bagi pertumbuhan dan perkembangan Kepiting Uca, hal ini sesuai dengan pendapat Suprayogi et al. (2014), yang menyatakan bahwa $\mathrm{pH}$ yang kurang dari 5 dan lebih dari 9 akan menciptakan suatu kondisi yang tidak menguntungkan bagi kehidupan makrozobentos termasuk krustasea salah satunya yaitu Kepiting Uca.

Nilai salinitas berkisar antara 19,5-30,8 ppt. Hidayat (2011) menyatakan bahwa Kepiting Uca dapat hidup dengan baik pada kisaran salinitas 10-35 ppt. Hal ini menunjukkan bahwa salinitas di kawasan ekosistem mangrove Kampoeng Kepiting msih dapat menunjang pertumbuhan dan kehidupan Kepiting Uca.

\subsection{Hubungan Kelimpahan Kepiting Uca dengan} kandungan c-organik

Hasil analisis hubungan kelimpahan Kepiting Uca dengan kandungan bahan organik pada setiap stasiun ditunjukkan pada Gambar 2.

Kandungan c-organik yang diperoleh dari hasil pengambilan data pada setiap stasiun antara 0,630$3,450 \%$ (Tabel 5). Kandungan c-organik dalam substrat bersumber dari hasil proses dekomposisi serasah (Aida et al., 2014). Tingginya kandungan bahan organik berasal dari penguraian serasah daun, ranting dan kayu dari mangrove (Hidayat, 2011). Hubungan kandungan c-organik dengan kelimpahan Kepiting Uca (Gambar 2) koefisien determinasi $\mathrm{R}^{2}$ sebesar 0,8311 yang artinya 83\% kandungan c-organik mempengaruhi kelimpahan Kepiting Uca. Hasil analisis perhitungan korelasi menunjukkan adanya hubungan positif yang kuat antara kandungan c-organik dengan kelimpahan Kepiting Uca yaitu dengan didapatkannya nilai korelasi sebesar 0,911. Semakin tinggi nilai kandungan c-organik, maka semakin tinggi pula kelimpahan total Kepiting Uca pada daerah tersebut.

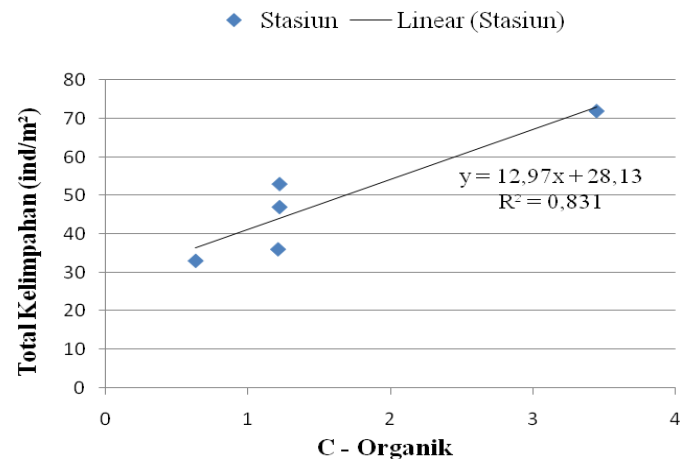

Gambar 3. Hubungan Kelimpahan Kepiting Uca dengan kandungan c-organik 


\section{Simpulan}

Terdapat 10 jenis Kepiting Uca yang ditemukan di kawasan mangrove Kampoeng Kepiting, TubanBali yaitu Uca yang ditemukan yaitu Uca demani, Uca coarctata, Uca dussumieri, Uca bellator, Uca lactea perplexa, Uca tetragonon, Uca chlorophthalmus crassipes, Uca lactea annulipes, Uca triangularis, dan Uca vocans. Kelimpahan Kepiting Uca tertinggi terdapat pada stasiun 4 yang memiliki kandungan c-organik tertinggi dengan kondisi substrat lumpur halus, sedangkan kelimpahan Kepiting Uca terendah terdapat pada stasiun 5 dengan kandungan c-organik terendah. Kandungan corganik memiliki hubungan yang kuat dengan kelimpahan Kepiting Uca di kawasan mangrove Kampoeng Kepiting..

\section{Ucapan Terimakasih}

Penulis mengucapkan terimakasih kepada pihak Kampoeng Kepiting yang telah memberi ijin untuk melakukan penelitian di Kawasan Hutan Mangrove Kampoeng Kepiting; DIKTI yang telah memberikan Beasiswa Bidik Misi; serta semua pihak yang membantu kelancaran penelitian.

\section{Daftar Pustaka}

Aida, G. R., Wardiatno, Y., Fahrudin, A., \& Kamal, M. M. (2014). Produksi serasah mangrove di pesisir Tangerang, Banten. Jurnal Ilmu Pertanian Indonesia, 19(2), 91-97.

Arsana, I. N. (2010). Struktur popolasi kepiting Uca triangularis di pantai Serangan, Bali. Jurnal Widya Biologi, 1(1), 18-25.

Bernini, E. L. A. I. N. E., \& Rezende, E. (2010). Litterfall in a mangrove in Southeast Brazil. Pan-American Journal of Aquatic Sciences, 5(4), 508-519.

Budiman, C. C., Maabuat, P. V., Langoy, M. L., \& Katili, D. Y. (2014). Keanekaragaman Echinodermata di pantai Basaan Satu Kecamatan Ratatotok Sulawesi Utara. Jurnal Mipa Unsrat Online, 3(2), 97-101.

Cannicci, S., Bartolini, F., Dahdouh-Guebas, F., Fratini, S., Litulo, C., Macia, A., \& Paula, J. (2009). Effects of urban wastewater on crab and mollusc assemblages in equatorial and subtropical mangroves of East Africa. Estuarine, Coastal and Shelf Science, 84(3), 305317.

Crane, J. (2015). Fiddler crabs of the world: Ocypodidae: genus Uca. New Jersey, USA: Princeton University Press.

Foth, H. D. (1984). Dasar-Dasar Ilmu Tanah. Terjemahan Purbayanti, E. D. Dwi R. L. \& Rayahayunimg, T. Yogyakarta, Indonesia: Gajah Mada University Press.
Hamidy, R. (2012). Struktur dan keragaman komunitas kepiting di kawasan hutan mangrove stasiun kelautan Universitas Riau, Desa Purnama Dumai. Jurnal Ilmu Lingkungan, 4(2), 81-91.

Hidayat, J. W. (2011). Metode Pengendalian Wideng (Sesarma spp) Hama Bibit Mangrove melalui Kegiatan Budidaya Kepiting Bakau Scylla spp. Bioma, 13(1), 2533.

Holtermann, P., Burchard, H., \& Jennerjahn, T. (2009). Hydrodynamics of the Segara Anakan lagoon. Regional Environmental Change, 9(4), 245-258.

Loviasari, N., As-syakur, A. R., Faiqoh, E., Dirgayusa, I. G. N. P., \& Wiyanto, D. (2018). Struktur Komunitas Uca Sp Di Kawasan Teluk Benoa Pada Karakteristik Substrat Yang Berbeda. Journal of Marine And Aquatic Sciences, 4(1), 141-150.

Milner, R. N. C., Detto, T., Jennions, M. D., \& Backwell, P. R. Y. (2010). Hunting and predation in a fiddler crab. Journal of ethology, 28(1), 171.

Muramatsu, D. (2009). To build or not to build-or to destroy burrow hoods in a population of Uca lactea. Journal of Crustacean Biology, 29(3), 290-292.

Muramatsu, D. (2010). Sand structure construction in Uca lactea (de haan, 1835) is related to tidal cycle but not to male or female densities. Crustaceana, 83(1), 2937.

Murniati, D. C. (2009). Perbandingan luas tutupan spoon tiped setae maksiliped kedua pada Uca spp. (brachyura: ocypodidae). Zoo Indonesia, 18(1), 1-8.

Murniati, D. C. (2010). Keanekaragaman Uca spp dari segara-anakan, Cilacap, Jawa Tengah sebagai pemakan deposit. Fauna Indonesia, 9(1), 19-23.

Natania, T., Herliany, N. E., \& Kusuma, A. B. (2017). struktur komunitas kepiting biola (Uca spp.) di ekosistem mangrove desa kahyapu Pulau Enggano. Jurnal enggano, 2(1), 11-24.

Penha-Lopes, G., Bartolini, F., Limbu, S., Cannicci, S., Kristensen, E., \& Paula, J. (2009). Are fiddler crabs potentially useful ecosystem engineers in mangrove wastewater wetlands?. Marine Pollution Bulletin, 58(11), 1694-1703.

Pratiwi, R. (2012). Asosiasi Krustasea di ekosistem padang lamun perairan Teluk Lampung. ILMU KELAUTAN: Indonesian Journal of Marine Sciences, 15(2), 66-76.

Sunaryo, A. I. (2014). Karakteristik dan Morfologi Liang Bioturbasi Kepiting di Kawasan Reklamasi Mangrove Muara Angke Kapuk-Jakarta. Maspari Journal, 4(2), 203-214

Suprayogi, D., Siburian, J., \& Hamidah, A. (2014). Keanekaragaman Kepiting Biola (Uca spp.) di Desa Tungkal I Tanjung Jabung Barat. Biospecies, 7(1), 6676.

Watiniasih, N. L. (2015). Jenis dan sebaran Uca spp. di kawasan hutan mangrove Benos, Badung Bali. Jurnal Widya Biologi, 6(2), 77-89. 
Weis, J. S., \& Weis, P. (2004). Behavior of four species of Indonesia. Hydrobiologia, 523(1), 47-58. fiddler crabs, genus Uca, in southeast Sulawesi,

(c) 2017 by the authors; licensee Udayana University, Indonesia. This article is an open access article distributed under the terms and conditions of the Creative Commons Attribution license (http://creativecommons.org/licenses/by/3.0/). 